\title{
Alterations in Cell Signalling Pathways in Breast Cancer Cells After Environmental Exposure
}

K.S. Kulp, S.M. McCutcheon-Maloney, L.M. Bennett

February 1, 2003

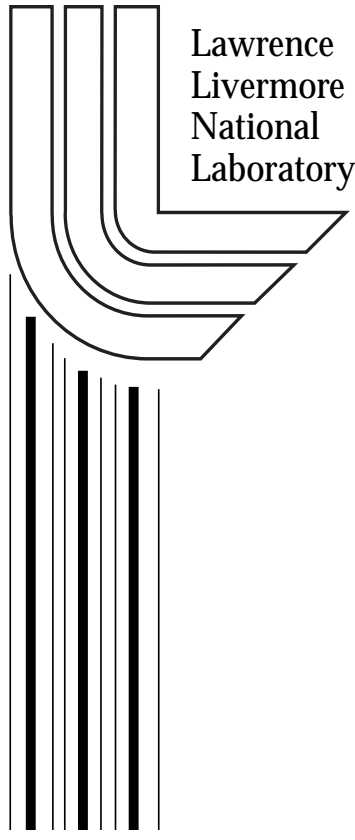




\section{DISCLAIMER}

This document was prepared as an account of work sponsored by an agency of the United States Government. Neither the United States Government nor the University of California nor any of their employees, makes any warranty, express or implied, or assumes any legal liability or responsibility for the accuracy, completeness, or usefulness of any information, apparatus, product, or process disclosed, or represents that its use would not infringe privately owned rights. Reference herein to any specific commercial product, process, or service by trade name, trademark, manufacturer, or otherwise, does not necessarily constitute or imply its endorsement, recommendation, or favoring by the United States Government or the University of California. The views and opinions of authors expressed herein do not necessarily state or reflect those of the United States Government or the University of California, and shall not be used for advertising or product endorsement purposes.

This work was performed under the auspices of the U. S. Department of Energy by the University of California, Lawrence Livermore National Laboratory under Contract No. W-7405-Eng-48.

This report has been reproduced directly from the best available copy.

Available electronically at http://www.doc.gov/bridge

Available for a processing fee to U.S. Department of Energy

And its contractors in paper from

U.S. Department of Energy

Office of Scientific and Technical Information

P.O. Box 62

Oak Ridge, TN 37831-0062

Telephone: (865) 576-8401

Facsimile: (865) 576-5728

E-mail: reports@adonis.osti.gov

Available for the sale to the public from

U.S. Department of Commerce

National Technical Information Service

5285 Port Royal Road

Springfield, VA 22161

Telephone: (800) 553-6847

Facsimile: (703) 605-6900

E-mail: orders@ntis.fedworld.gov

Online ordering: http://www.ntis.gov/ordering.htm

OR

Lawrence Livermore National Laboratory

Technical Information Department's Digital Library

http://www.llnl.gov/tid/Library.html 


\section{Purpose:}

Recent human epidemiological studies suggest that up to $75 \%$ of human cancers can be attributed to environmental exposures. Understanding the biologic impact of being exposed to a lifetime of complex environmental mixtures that may not be fully characterized is currently a major challenge. Functional endpoints may be used to assess the gross health consequences of complex mixture exposures from groundwater contamination, superfund sites, biologic releases, or nutritional sources. Such endpoints include the stimulation of cell growth or the induction of a response in an animal model. An environmental exposure that upsets normal cell growth regulation may have important ramifications for cancer development. Stimulating cell growth may alter an individual's cancer risk by changing the expression of genes and proteins that have a role in growth regulatory pathways within cells. Modulating the regulation of these genes and their products may contribute to the initiation, promotion or progression of disease in response to environmental exposure.

We are investigating diet-related compounds that induce cell proliferation in breast cancer cell lines. These compounds, PhIP, Flor-Essence ${ }^{\circledR}$ and Essiac $®$, may be part of an everyday diet. PhIP is a naturally occurring mutagen that is formed in well-cooked muscle meats. PhIP consistently causes dose-dependent breast tumor formation in rats and consumption of well-done meat has been linked to increased risk of breast cancer in women. Flor-Essence $®$ and Essiac $®$ herbal tonics are complementary and alternative medicines used by women who have been diagnosed with breast cancer as an alternative therapy for disease treatment and prevention.

The long-term goal of this work is to identify those cellular pathways that are altered by a chemical or biologic environmental exposure and understand how those changes correlate with and or predict changes in human health risk. This project addressed this goal by measuring alterations in cell growth pathways in the human MCF-7 breast cancer cell line using functional cell proliferation and reporter assays in combination with new macroarray technology after exposure to PhIP and the herbal tonics.

\section{Specific Aims:}

Aim 1: Establish the effect of PhIP and Flor- Essence ${ }^{\circledR}$ in functional assays that characterize cell growth and receptor activation after exposure.

Aim 2: Identify alterations in the expression of known genes and proteins involved in growth regulation pathways. RNA and protein extracts from exposed and unexposed MCF-7 cells will be compared using Myria ${ }^{\mathrm{TM}}$ macroarrays which profile p53- regulated human genes and transcription factors. These results will be correlated to the functional results obtained in Aim 1. 
Aim 3: Determine whether the putative chemopreventive (Flor-Essence $\AA$ ) can protect against or has a protective effect on carcinogen exposure by treating the cells with both the herbal tonic and PhIP.

\section{Activities:}

Aim 1: Using cell proliferation assays we determined that these compounds have a pronounced effect on breast cancer growth control. PhIP treatment resulted in a statistically significant increase in estrogen-dependent cell growth pathways compared to untreated cells, which is a novel finding for a mutagen that was previously known to primarily cause DNA damage. Cell proliferation assays demonstrated a 20 to $30 \%$ increase in cell number after PhIP treatment, comparable to the increase seen when the cells are treated with estrogen. The herbal tonics, which contain extracts of herbs known or suspected to be estrogenic, stimulated cell growth as much as twofold and increased estrogen receptor activity four- to five-fold. Using a standard reporter assay that specifically measures estrogen receptor activation, we determined that PhIP and the herbal tonics were able to activate the estrogen receptor, and that this activation could be blocked by the pure anti-estrogen ICI 182,780. Further screening of other hetercocyclic amines showed that PhIP was the only compound of this type that was able to activate the estrogen receptor and that other heterocyclic amines actually acted as anti-estrogens. This novel finding may have important ramifications for cancer research because it indicates that compounds previously thought to be tumor initiators can also act as endocrine disruptors.

In contrast to PhIP, which only weakly activated the estrogen receptor, the herbal tonics were able to activate the receptor to levels that are comparable to physiologically relevant concentrations of estrogen. Taken with the proliferation data, these results indicate that these alternative medicines may have undesirable effects on breast tumor growth.

Aim 2: Attempts to relate the results from these functional assays to the array technology were not as successful. RNA and nuclear proteins were isolated from MCF-7 cells that have been exposed to PhIP or Flor-Essence $®$ and hybridized to Myria $^{\mathrm{TM}}$ gene and protein macroarrays. Although each individual array experiment was successful, the results obtained from multiple repetitions were not consistent. More work is needed to refine this innovative technology.

Aim 3: Co-incubating the cells with PhIP and Flor-essence ${ }^{\circledR}$ produced an additive response that increased estrogen receptor response sixfold and cell proliferation to levels not observed with either compound alone. This suggests that rather than being chemopreventive, these herbal tonics may act in an additive fashion to promote breast cancer cell growth. This may have important implications for breast cancer survivors that use herbal tonics while continuing to eat over-cooked meats. 
Our results show that these dietary compounds stimulate cell growth through an estrogen receptor-dependent pathway. Because estrogen and estrogen-like compounds (xenoestrogens) are known risk factors for breast cancer, these results suggest that exposure to these compounds may increase breast cancer risk. Further research is needed to determine how these environmental exposures may modulate the expression of genes and proteins involved in growth regulation and how this may contribute to the initiation, promotion, or progression of disease.

\section{Outcomes:}

The preliminary results generated by this LDRD have been used to obtain further funding through grant proposals submitted to the National Institute of Health, and the California Breast Cancer Research Program. An abstract describing these results was chosen by The American Society of Cell Biology to be featured in the annual meeting pressbook and the work was subsequently described in the Tri Valley Herald. In addition, the results from this proposal will comprise at least two manuscripts that are being prepared.

This project supports the DOE mission to improve human health and NNSA missions in counterterrorism and homeland security by improving our understanding of real-life exposure to complex environmental mixtures. The methods developed here can be directly applied to other defense-related biological research, including cellular response to infection. 